\title{
Influences of Eastern Philosophy in Emerson's Writings
}

Giri Himal (Ph.D.Scholar)

\begin{abstract}
The paper explores and critically examines how the Vedic thought with specific reference to Brahma, the Bhagavad Gita, and the laws of Karma have influenced Ralph Waldo Emerson's prose works. The project shows an analysis of Emerson's works in relation to the Vedic philosophy. Therefore, criticisms and readings on his essays build up the background to illustrate the claim. The paper also demonstrates that there has been an impetus of Eastern philosophy on western writers including Ralph Waldo Emerson. The amalgam of Eastern philosophy and western vision beautifies the texture of this article. The readers will benefit from the knowledge of American transcendentalism.
\end{abstract}

Key Words: Brahma, Karma, Philosophy, Emerson, Transcendentalism

\section{Introduction}

The impetus of the Vedic literature on American transcendentalism is what the research aims to justify. The Eastern philosophy has been serving as a source of knowledge for the Western thinkers and philosophers, like Ralph Waldo Emerson. He accepts, "I owed a magnificent day to the Bhagavad Gita. It was the first of books; it was as if an empire spoke to us, nothing small or unworthy, but large, serene, consistent, the voice of an old intelligence . . . (Emerson, 1914). Henry David Thoreau read extensively the Vedic texts. Besides, he also read "Shakuntalam", "Vishnupuran", "Haribansa", etc. He is said to have given "oriental wisdom an occidental shrine". Another American transcendentalist, Walt Whitman, was also greatly influenced by the Vedic thought. Emerson termed Whitman's "Leaves of Grass" a blending of the Bhagavad Gita and the New York Herald.

\section{Analysis}

The ideas and philosophy of Vedas have influenced Emerson's prose works. Emerson writes in his essay "Nature" that "When a faithful thinker, unyielding to detach every object from personal relations, and see it in the light of thought, shall, at all same time, kindle science with the fire of the holiest affections, then will God go forth anew into the creation." The Rig Veda mentions about detached and attached Karma as follows: 
Like two birds of beautiful wings, there are two spirits i.e. the finite and the supreme. And they both are knit together in the relation of pervaded and pervader but with bonds of friendship. Like the birds, the soul and Great Soul reside on the same tree i.e. of the matter. This tree is also eternal like God. One of the twin i.e. the finite spirit or soul enjoys the sweet and ripe fruit of Karma produced by its actions, whereas the other i.e. the Supreme Spirit or God simply observes around as an omniscient without enjoying its fruitage. (Mandala I, Hymn 164, Mantra 20)

Emerson states in "Nature" about the stars, the preachers of beauty, which come out every night and "light the universe with their admonishing smile". He further writes about the nature and says, "What angels invented these splendid ornaments, these rich conveniences, this ocean of air above, this ocean of water beneath, this firmament of earth between? This zodiac of lights, this tent of dropping clouds, this striped coat of climates, this fourfold year?" These expressions of him about the nature have received impacts from the Vedic descriptions of nature. Vedic picturesque descriptions of azure oceans can be observed with constant rhythmical reverberant waves beating against the shore, the lustrous firmament with illuminating stars, the snow-clad mountains with loftiest peaks gazing with utter astonishment, murmuring rivers chanting divine hymns that flow towards the ocean in quest of divinity. Luminous sun spreads bright rays of golden hues, fascinating earth consisting of heights, slopes, and plains, bearing in her bosom the precious herbs, which possess healing powers. It radiates dawn spreading gorgeous beams in the radiant void of the sky to awaken the seekers of truth, birds of beauteous wings and lovely plumage, melodious music of the retreating waves, transparent drops of dews glimmering with hidden divinity, fascinating fountains bursting into sweetest melodies, soothing rhythm of the water falls, roaring clouds with pouring rains, etc (Talreja, 1982).

Emerson mentions in "The Over-Soul"," . . great nature in which we rest, as the earth lies in the soft arms of the atmosphere: that Unity, that Over-Soul, within which every man's particular being is contained and made one with all other." The Rig Veda has similar ideas in its Mandala I, Hymn II, and Mantra I, which reads like this, "The Lord is diffused on every side like the ocean, who is the Supreme Charioteer and master of the souls possessing the chariots in the form of bodies."

The influence of the Upanishads on Emerson's essays appears at large. Emerson expresses in "Experience", "God says to man, 'you will not expect' . . . All writing comes by the grace of God and all doing and having ... I can see nothing at last, in success or failure, than more or less of vital force supplied from the Eternal. The results of life are incalculated and incalculable." The Isa Upanishad (Mantra 2) already mentioned similar ideas, "By doing karma, indeed, should one wish to live here for a hundred years . . . Karma may not 
cling to you". The Gita's famous verse (Shankhya Yoga, Verse 47) addressed to warrior Arjuna by Lord Krishna had it, "Seek to perform your duty; but lay not claim to its fruits. Be you not the producer of the fruits of karma; neither shall you lean towards inaction."

Similarly, many studies have been on Emerson's works that demonstrate the impacts of the Vedic literature on his writings. Scholars view on his writings ranging from various aspects including impetus of the Eastern philosophy. Swami B.G. Narasingha mentions in an article that an intellectual movement flourishing in the United States from 1839 to 1866 known as transcendentalism was run by members of the Transcendental Club or Circle, the prominent members of which were Ralph Waldo Emerson, Henry David Thoreau, James Freeman Clark, Amos Bronson Alcott and Margaret Fuller. "Their collective achievement in the quality of style and in-depth philosophical insight has yet to be surpassed in American literature. And their major influence, without exception, was the Vedic literatures of India." Emerson greatly appreciated Vedantic literatures. His (and Thoreau's) writings contain many thoughts from Vedic philosophy (www.archaeologyonline.net).

Laxmi Kasturi's study has it that the Vedic beliefs migrated to the West and there was an influence of the Vedic literature on the life and writing of Emerson. She writes that Emerson had however, "concealed his Vedic influence in his public writing and lectures". She mentions, "Emerson understood how the Vedic ideas influenced the Greeks and Romans and shows how Emerson used Greek and Latin sources to convey the Vedic concepts" (Kasturi, Transcendentalism). Likewise, a research with the theme of "The Voice of an Old Intelligence", which is available at the University of Hong Kong Libraries, states that Emerson, Thoreau and Walt Whitman "set the template for American Veda. They absorbed Vedic ideas and adapted them to their own thoughts. . . Every high school or college student who reads Emerson's essays or Thoreau's Walden or Whitman's Leaves of Grass is getting a taste of India, whether they know it or not" (http://americanveda.com).

About Emerson, D.H. Lawrence viewed, "I like his wild and genuine belief in the Over-Soul and the inrushes he got from it. But it is a museum-interest. Or else it is a taste of the old drug to the old spiritual dope-fiend in me" (Newton, 1966). Sardar (2013) has studied the nature of Brahma, Karma, and Maya in the works of Emerson and has concluded that despite a little bit of contradiction, much of Emerson's belief is aligned with the Indian philosophical and religious thought (Riepe, 1967). Three basic concepts of Brahma, namely, formed and formless Brahma, Atman, and Maya, exerted much influence on Emerson's writings (1-6). However, his findings tell very little about the concordance and contrast between the Emersonian transcendentalism and Vedic sublimity. In yet another article, Sardar compares the Emersonian and Tagorian perspectives and remarks: 
Nonetheless, an intellectual correspondence between these two writers is surprisingly identifiable. Both of them share many common grounds. For instance, they reject blind formalism in religion and strive to reach for an original and direct relationship with God. Relying on intuition, they establish an idealistic philosophy and maintain their belief in idealism throughout their lives. In addition, both of them depend heavily on Indian philosophical and religious thought for knowledge and inspiration. (19)

American Transcendentalism Web mentions that Emerson is the Supreme Critic on the errors of the past and the present, and the only prophet of that which must be, is that great nature in which we rest. The earth lies in the soft arms of the atmosphere; that Unity, that Over-soul, within which every man's particular being is contained and made one with all other. Common heart, of which all sincere conversation is the worship, to which all right action is submission that overpowers reality which confutes our tricks and talents and constrains everyone to pass for what he is, and to speak from his character. We live in succession, in division, in parts, in particles. Meantime within man is the soul of the whole; the wise silence; the universal beauty, to which every part and particle is equally related; the eternal ONE. In addition, the deep power in which we exist, and whose beatitude allaccessible to us is not only self-sufficing and perfect in every hour, but the act of seeing and the thing seen, the seer and the spectacle, the subject and the object, are one. We see the world piece by piece, as the sun, the moon, the animal, the tree; but the whole, of which these are the shining parts, is the soul (1).

The same Omniscience flows into the intellect, and makes genius. Much of the wisdom of the world is not wisdom, and the most illuminated class of men is no doubt superior to literary fame, and is not writers. Among the mass of scholars and authors, we feel no hallowing presence; we are sensible of a knack and skill rather than of inspiration; they have a light, and know not whence it comes, and call it their own; their talent is some exaggerated faculty, some overgrown member, so that their strength is a disease. In these instances the intellectual gifts do not make the impression of virtue, but almost of vice; and we feel that a man's talents stand in the way of his advancement in truth. Nevertheless, genius is religious. It is a larger imbibing of the common heart. It is not anomalous, but more like, and not less like other men emphasized in American Transcendentalism Web.

Though "self-reliance” is an idea that frequently appears in Emerson's published and unpublished works, it is notoriously difficult to define. In the words of Lawrence Buell, this is most likely because, "Self-Reliance is not reducible to a theology, a social theory, an epistemology, an aesthetic, an educational program", or anything systemic in the conventional sense of the word (Buell 63). Indeed, the operative word in the phrase is "self", stressing the highly personal with an emphasis on practice. In championing this doctrine, 
Emerson consistently points outside the text and at the reader, asking her to "believe your own thought, to believe that what is true for you in your private heart, is true for all [people], — that is genius” ("Self-Reliance" 121). Emerson’s work only sketches a broad outline of what it means to practice self-trust, a strictly functional and unadorned map with which the reader can fill in using biographical details. Yet the self-reliant path is not an easy one. As Emerson explains in his journal-in an entry dated contemporaneously with the composition of the essay "Self-Reliance"- “And must I go \& do some what if I would learn new secrets of Self-reliance? For my chapter is not finished. But self-reliance is precisely that secret, - to make your supposed deficiency redundancy. If I am true, the theory is, the very want of action, my very impotency shall become a greater Excellency than all skill \& toil” (Journals VII: 521). What emerges in the published essay is, "envy is ignorance; that imitation is suicide; that [the self-reliant individual] must take himself for better, for worse, as his portion; that though the wide universe is full of good, no kernel of nourishing corn can come to him but through his toil bestowed on that plot of ground which is given to him to till” ("Self-Reliance" 121). As such, self-reliance is not an exercise is perfectionism. Instead, it is about embracing your deficiencies and realizing that facing individual limitations while obeying instinct is infinitely better than mimicking the example of another. Prevalent in personal shortcoming is the pith of individuality, the particularized raw material with which the subject can make her mark upon the world.

Self-reliance, then, is partially dependent upon personal deficiency, and Emerson found that the best way to banish those deficiencies lies in the process of reading, which was an attempt in which he was perennially captivated. As an understudied constituent of selfreliance, Emersonian reading rests on-what appears to be-a foundational paradox. How is it that an indispensable element of cultivating self-trust waits in the careful study of other people and phenomena? Henry James is among those who have identified this paradox, and James suggests that the paradox "was because the independence that he had in his eye was an independence without ill-nature, without rudeness, and full gentle amiabilities, curiosities, and tolerances” (James “Emerson” 622). James eventually aligns this paradox as evidence that Emerson “never really mastered the art of composition” (622), but Emerson's use of quotation and allusion throughout his published work is more deliberate than James allows. Emerson explains in an 1837 journal entry, “The office of reading is wholly subordinate...I see \& do, chiefly as it affords me new language, \& power of illustration ...I get thereby a vocabulary for my ideas. I get no ideas” (Journals V, 343). An idea-or a genuine thought - for Emerson, is a component of absolute, individual instinct and an aspiration towards a universal truth, but what reading does is allow the subject to make her deficiencies redundant using the words of another as a template. In another entry in the same year, Emerson goes on to say that, the author is only a more or less awkward translator of 
entities in your consciousness, which you have also, your own way of seeing, perhaps of dominating. Say then, instead of too timidly pouring into his incomprehensible sense that he has not succeeded in rendering back to you your awareness: he has not succeeded, now let another try (Journals V, 390).

For Emerson: to identify an adequate translator-a supplier of a luminous vocabulary-with whom the reader can decode her encrypted consciousness. Emerson makes this clear in the essay "Self-Reliance," saying, "In every work of genius we recognize our own rejected thoughts: they come back to us with a certain alienated majesty" ("SelfReliance" 121). It is discovered that what we had once codified as our own powerlessness now reveals itself, in another's work, to be quite the contrary. Identifying our own alienated thoughts in a book only acknowledges a new way to say what has already been felt to be true: what once was deficient now reveals itself redundant.

Emerson mentions about his personal loss in "Experience", that he becomes entirely mindful that there are too many possible meanings widespread in each word. It forces him to admit, "We live admit surfaces, and the true art of life is to skate well on them" ("Experience" 204). Actually, Emerson in this essay is very aware that there is completely languages-here, the language of grief-which he does not have access to, for he describes being unable to properly lament for his son in a meaningful way. Emerson discovers that Waldo’s death “does not touch [him]: something which I fancied was a part of me, which could not be torn away without tearing me, nor enlarged without enriching me, falls off from me, and leaves no scar" ("Experience" 200). However, what is exceptional about the essay is that Emerson is still attempting to advance self-reliance in him and in his reader, though it is clear that what he means by "deficiency" has delicately evolved. Emerson attempts to portray whole worlds of experience that he does not have access to, which unavoidably results in gaps between word and thing. At the same time, however, the form of the work-diction and syntax, particularly-autonomously pushes to the limits of signification to attempt to summarize powerfully personal and unusual emotions in language.

Reading with self-reliance does not deconstruct a text, but rather affectionately obliterates it. Actively lending our biographical feature to fill in the semantic gaps endemic in any book simultaneously renders the original indecipherable while destroying barriers between author and reader in favor of the worldwide sense of the idea. At the same time, however, it is the reader's duty to recognize when an author has gone where she cannot follow-as is the case in "Experience"-and allow that some experiences are best signified outside the realms of language. Emerson kept his enthusiastic reading interests throughout his literary career and, towards the end of his life in 1867, he still detailed the importance of cultivating self-reliance in conjunction with his favorite past time: 
I suppose every old scholar has had the experience of reading something in a book which was significant to him, but which he could never find again. Sure, he is that he read it there; but no one else ever read it, nor can he find it again, though he buys the book, and ransack every page. (Journals, 320)

Of all the passages in Emerson's journals, this is the most unpredictably bittersweet. While the experience he details sadly portends the disastrous memory loss that would trouble him towards the end of his life, it also offers a kind of model for, what he found to be, an ideal mode of reading. This entry offers two contrasting interpretations, but both work to exemplify an idea that is pursued in defining the ideal Emersonian reader. The literal explanation of this passage suggests that Emerson has ratified and assimilated the toil of another writer into his own thought and has simply forgotten its origin. However, this passage also leaves the prospect open that Emerson is attributing an original thought to some "forgotten" author and searches in vain for the text in which it first appeared.

\section{Conclusion}

When it is read in an Emersonian fashion and with self-reliance, similar difficulties inescapably present themselves. However, the close and active role that as readers of whole histories of thought in text-where the work is vivified and readers' experiences are ratified-is the key to nurturing self-reliance in ourselves and in others, for the misleading deficiencies in the external world have been made outmoded.

There are certainly hints along the way of a more naturalistic and practical, mysterious doctrine which yet speaks Emerson's characteristic religious language. "The soul which animates Nature," he says in "Behavior," "is not less significantly published in the figure, movement, and gesture of animated bodies, than in its last vehicle of articulate speech.” The moral idealist is a shrewd literary viewer of manners and deportment; and the focus on intuition arising overtly from nature is balanced by fine efforts to construe human society. Early on, Emerson's writings depended on the natural surroundings, since a reorientation and adaptation of traditional European thought was required in the new American environment. However, in his later writings, Emerson is more concerned with culture, religion, and philosophies. After all, the article has revealed how the Indian thoughts have influenced Emerson's prose works.

\section{Works Cited}

Buell, Lawrence., ed. The American Transcendentalists. New York: The Modern Library, 2006.

Emerson, Ralph Waldo. Emerson's Prose and Poetry. Ed. Joel Porte and Saundra Morris. New York: W.W. Norton \& Company Inc., 2001. 
Patan Pragya (Volume: 6, Number: 1 2020)

. . . "Nature." In Atkinson, Brooks. 2000. The Essential Writings of Ralph Waldo Emerson. New York: The Modern Library, 2000.

. . . " "The Conduct of Life". Boston, MA: James R. Osgood and Co., 1876. Print.

. . . “The American Scholar.” Ralph Waldo Emerson-Texts. Jones Johnson Lewis, 3 Sept. 2009.

. . . 2000b. "The Spiritual Laws." In Atkinson, Brooks. 2000. The Essential Writings of Ralph Waldo Emerson. New York: The Modern Library, 2000.

James, Henry. “Emerson”. Emerson's Prose and Poetry. Ed. Joel Porte and Saundra

Morris. New York: W.W. Norton \& Company Inc., 2001.

Sardar M. Anwaruddin. "Emerson’s Passion for Indian Thought." International Journal of Literature and Arts. Vol. 1, No. 1, 2013, pp. 1-6.

Whitman, Walt. Leaves of Grass and Other Writings. Ed. Michael Moon. New York:

W.W. Norton \& Company, Inc., 2002. 